\title{
Pelas franjas dos santuários: turismo, fé e religião em flashes etnográficos
}

\author{
Through the outskirts of sanctuaries: \\ Tourism, faith and religion on ethnographic flashes
}

Emerson José Sena da Silveira*

\begin{abstract}
Resumo
Neste artigo discute-se a relação entre turismo, fé e religião em torno dos santuários, a partir de três vivências etnográficas revisitadas em forma de flashes multissituados, com revisão bibliográfica parcial. O santuário, em sentido lato, abarca um núcleo central e uma extensa franja, espaciais e simbólicos. Entre o centro e a periferia estendem-se gradações, continuidades e descontinuidades. O santuário, desta forma, é compreendido neste artigo mais por suas sombras e simulacros do que por sua luminosa presença e esplendor, mais pela periferia do que pela centralidade. A questão proposta aqui remete aos espaços intermediários onde religião e turismo se esbarram, se misturam e se contrapõem. Foram três os espaços estudados a partir da metodologia etnográfica, Aparecida (SP), Canção Nova (SP) e AshramVrajabhumi (RJ). O presente texto defende, portanto, que as franjas dos santuários permitem a reverberação de identidades ambíguas e oscilantes entre uma integridade-unicidade (fé) e uma nãointegridade/não-unicidade (turismo).
\end{abstract}

Palavras-Chave: Religião; Santuário; Fé; Turismo; Modernidade

\begin{abstract}
This paper discusses the relationship between tourism, faith and religion around sanctuaries, based on three ethnographic experiences revisited in the form of multissituated flashes - and a partial bibliographical revision. The sanctuary, in a broad sense, embraces a central nucleus and an extensive fringe, spatially and symbolically. Between the center and the outskirt there are gradations, continuities and discontinuities. In this way, this paper understands the sanctuary through its shadows and simulacra, rather than its luminous presence and splendor, through the periphery rather than through its centrality. The question posed here refers to the intermediate spaces where religion and tourism meet by confluence, mixing and contrasting among each other. This paper analyzes three spaces from an ethnographic methodology: Aparecida - SP, Canção Nova - SP, and Ashram-Vrajabhumi - RJ. Therefore, we argue that the outskirts of sanctuaries allow the reverberation of ambiguous and oscillating identities between and integrity-oneness (faith) and a non-integrity/non-uniqueness (tourism).
\end{abstract}

Keywords: Religion; Sanctuary; Faith; Tourism; Modernity.

Artigo submetido em 16 de fevereiro de 2018 e aprovado em de abril de 2018.

* Doutor em Ciência da Religião pela UFJF (2006) e Professor da UFJF. País de origem: Brasil. E-mail: emerson.pesquisa@gmail.com

Horizonte, Belo Horizonte, v. 16, n. 49, p. 136-165, jan./abr. 2018 - ISSN 2175-5841 


\section{Introdução}

Apresento neste texto três experiências etnográficas ${ }^{1}$ que, embora intermitentes no tempo e no espaço, lançam um argumento teórico, de chofre colocado nesta introdução, a saber, a relação entre a zona central do santuário e suas periferias, a partir das experiências de indivíduos e grupos religiosamente engajados. Objetivei, com essa pesquisa, e lastreado em metodologia qualitativa, a relação entre peregrinos, santuários e turismo. Para tanto, acompanhei, em várias ocasiões descritas no corpo do texto, o deslocamento de grupos e indivíduos em suas buscas/deslocamentos "espirituais-religiosas", por três santuários, dois católicos e um esotérico-new age. O nexo que vinculou as escolhas dos três lugares foi dado pelas redes de relações entre os grupos e indivíduos pesquisados, verificados a posteriori, e que apontavam para duplas pertenças ou saídas do catolicismo carismático e ingresso no mundo new age.

As escolhas e opções teórico-metodológicas qualitativas trazem, sempre, planos, hipóteses e questões iniciais que são transformados ao longo do contato do pesquisador com a realidade vivida e pulsante, uma mistura de paixão de sofrimento ${ }^{2}$. Lembra Geertz (2008) que, em uma pesquisa de aporte etnográfico, os fatos não existem para serem colhidos, não estão dados e, por isso, planos e hipóteses não são “objetivos”, e controlados a priori. Daí que a tarefa seja difícil e densa, pois, ao entrar no "campo", num primeiro momento, tudo aparece como imbricado, assimétrico, fragmentário e descontínuo. Posteriormente, à medida em que as informações são analisadas e o texto nasce, emergem distinção, simetria, totalidade e continuidade. 3

\footnotetext{
${ }^{1}$ Por questões de espaço, deixo ao leitor informar-se e aprofundar-se na questão do alcance, legitimidade, limites e pertinência do método etnográfico para o estudo da religião no campo da cultura, da religião e das Ciências, ou Ciência da Religião e Teologia. Indico alguns textos básicos: Geertz (2008), Marcus (1991), Montero (1993) e Silveira e Moraes Júnior (2017). Os "flashes" etnográficos deste texto compõem um mosaico que pode ser chamado de etnografia multissituada, ou seja, uma etnografia feita em distintos lugares e tempos que se articula em torno de um eixo semântico-propositivo. (CLIFFORD, MARCUS, 1986; CESARINO, 2014).

${ }^{2}$ Para maiores fundamentações das fases, etapas e estruturas do trabalho etnográfico, veja Urpi (2012).

${ }^{3}$ Leila Amaral, (2004, p. 31), ao realizar uma excelente apresentação das influências do pensamento hermenêutico sobre a antropologia, chama atenção para a crítica dos antropólogos pós-modernos ao modelo bem-comportado da antropologia modernista: "Os 'dilemas' e 'ironias' vividos pelos mais diversos antropólogos., diz Webster, expressam [...] uma experiência de campo fragmentada, vivido num processo de comunicação tenso, envolvendo trocas e negociações de rotinas entre antropólogos e informantes, numa dramática rotina". Imagine-se essas questões traspostas para as ciências da religião: os dilemas postos intensificam-se.
} 
O controle das variáveis e demais procedimentos metodológicos é feito $a$ posteriori, conforme a literatura pertinente aponta (BARREMAN, 1975; MINAYO, 2010). Inicialmente, os planos contemplavam uma distribuição equilibrada dos santuários, mas, por vicissitudes do campo, inafastáveis da pesquisa etnográfica 4 , o resultado da pesquisa foi divergente. Porém, como o foco concentrou-se, não na comparação entre santuários e suas relações centro/periferia, mas no inseparável duplo aspecto, a saber, a relação entre zona e centro do santuário a partir do deslocamento de pessoas/grupos engajados religiosamente, justificam-se as escolhas apresentadas. Para consolidar o controle qualitativo a posteriori, revisitei pesquisas etnográficas realizadas5 sobre deslocamentos de grupos religiosos, complementei as informações obtidas com re-visitas aos santuários e procurei amparo teórico (GIDDENS, 1991; TURNER, 2008; ROSENDHAL, 1996, 1999).

Com base nisso, proponho que a peregrinação dos grupos e indivíduos em torno e nos "santuários" expressa dois movimentos paradoxais: a dispersão e a concentração, a leveza e o peso, ligadas aos restos de uma identidade fixa e autocentrada.

A primeira experiência foi realizada em congresso de cura interior ${ }^{6}$ na cidade e no santuário de Aparecida, São Paulo, promovido por membros da renovação carismática católica. Na segunda, acompanhei um grupo de católicoscarismáticos em suas andanças à Canção Nova, um complexo conjunto de lazer, oração, consumo, evangelização e palco, com santuários. Na terceira, acompanhei

\footnotetext{
${ }^{4}$ É de amplo conhecimento que o método etnográfico, sistematizado e aperfeiçoado por Bronislaw Malinowski foi fruto de um imponderável e do toque do acaso. Esse jovem polonês, fazendo o seu doutorado em Antropologia na London School of Economics, era súdito austríaco e enquanto tal, na primeira guerra mundial, não poderia integrar a tripulação de um navio inglês, vendo-se obrigado a ficar quatro anos, até 1918, entre os territórios das ilhas Tulon, Trobriand e Austrália. (URPI, 2012).

${ }^{5}$ Toda pesquisa etnográfica acumula muitos dados em cadernos de campo, nem todos aproveitados. As informações neste artigo referem-se aos dados não aproveitados de algumas investigações (SILVEIRA, 2003 a; 2003b; 2014). Observação: o nome do autor, os títulos dos trabalhos e alguns dados das referências foram ocultados para evitar a identificação indireta de autoria por parte do avaliador. Após o resultado da avaliação, caso seja aprovado, o nome e os dados completos serão inseridos. Pesquisas sobre os católicos e os católicos carismáticos, como as realizadas por Steil (1998; 2001; 2004) e Camurça (1998; 2010), também apontam para esses destroços, em variadas combinações e inter-relações com santuários, oficiais e não-oficiais.

${ }^{6}$ A questão é ampla e complexa, com variados estudos, entre os quais de Csordas (1997). Não poderei aprofundar aqui por questões de espaço e estratégia metodológica. Em geral, cura interior trata-se da cura de emoções e memórias que causaram traumas, dores e sofrimentos nos indivíduos. Os carismáticos católicos criaram seminários encontros, estratégias, técnicas e uma vasta produção bibliográfica para demonstrar a validade da ideia e a eficácia do ritual religioso (CSORDAS, 1997).
} 
um grupo new age/esotérico em uma peregrinação para um fim-de-semana em um hotel-spa-esotérico, uma espécie de santuário pós-moderno. 7

A hipótese exploratória é a de que os santuários, entre sua zona central e periferias, constituem um espaço em que dois fenômenos convergem e configuram as identidades religiosas, a partir do deslocamento de grupos e pessoas espiritualmente ou religiosamente afetados, a saber: o esvaziamento da gravidade dos símbolos religiosos concomitante à reação contrária, a busca do peso. Seriam duas as maneiras como essa nova configuração identitária ocorreriam: a primeira delas refere-se à errância nômade nova-erista, que descanoniza tradições e ritos religiosos e não-religiosos - diversos e distantes no tempo e no espaço. Contribui para esse fenômeno, a "quebra das ortodoxias e de seus códigos originais" (AMARAL, 2003, p. 21), sem negar as crenças existentes, mantendo-as em estado de flexibilidade, provisoriedade, combinação, irresolução e indecisão, bem como recusando-se à fixação do sentido em signos. Trata-se de um “espírito sem lar” (AMARAL, 2000 e 2003). A segunda está ligada à obsessão em fixar significados em identidades seguras, desejosas de serem e estarem a salvo de flutuações heterodoxas, mas que para almejar a estabilização como identidade fechada, pronta, acabada, acopla-se aos meios mercadológicos e individualizantes.

O argumento das zonas periféricas dos santuários, entendidas como zonas de emergência de identidades contraditórias, sustenta-se na ideia de póstradicional, defendida por Giddens (2001): a defesa intransigente e repetitiva de uma suposta tradição. Isto é, a tentativa de refazer sua gravidade é um esvanecimento, uma saudade da ontologia, pois o que é autoevidente - ou o que é tido como uma realidade natural absoluta, segundo os tradicionalistas - prescinde da constante recorrência aos mecanismos de apologia de sua existência. Esses dois movimentos sugerem a perda da autoevidência e da naturalidade das identidades e símbolos religiosos que, doravante, estarão envolvidas em identidades irreverentes

\footnotetext{
${ }^{7}$ A pesquisa deu-se entre os anos de 1999 e 2006, cobrindo um período longo de observação. Acompanhei, individualmente e em grupo, deslocamentos de católicos, e outros grupos mais fluidos religiosamente, rumo a seminários, bandas e eventos da espiritualidade carismático-católica. Fiquei hospedado em Aparecida, Canção Nova e Teresópolis em diversos períodos de pesquisa, curtos e longos, a saber, 1999-2000, 2003-2006 e 2015-2016.
} 
e leves, por um lado, e pesadas e sérias, por outro. Uma questão puxa a outra e impõe-se, segundo algumas metodologias, uma definição exaustiva dos termos, no presente caso, "santuário", "turismo religioso" e "peregrinação”, o que remete a uma vasta bibliografia (EADE, SALNOW, 1991). As definições debatidas por autores especializados apresentam um variado espectro semântico-conceitual (STEIL, 1996; TURNER, TURNER, 1978). Porém, não mergulharei nessas discussões teóricas, mas apresentarei as pulsações dos sentidos a partir dos indivíduos e grupos religiosamente orientados que circulam pelos santuários, entre seu centro e suas franjas.

\section{Turismo, santuário e identidade}

Turismo religioso é um termo controverso (DIAS, 2003; SECALL, 2002; WERNET, 1992). No cotidiano, as mesclas ocorrem com frequência: festejos religiosos, modernas peregrinações, ${ }^{8}$ santuários/igrejas, megaeventos religiosos e atrativos naturais (cachoeiras mágicas, serras místicas). Ora, o turismo religioso é visto como uma nova forma de experiência cultural; ora é visto como a retomada de formas de vivência religiosa - como as peregrinações, mas profundamente transformadas, secularizadas, para alguns autores (WERNET, 1992).

O deslocamento turístico-religioso, misturado com as tradicionais peregrinações, faz parte do mercado de entretenimento, assim como de uma rede de pousadas, hotéis, agências de viagem, infraestrutura turística e agentes políticoculturais-religiosos - tais como secretarias de turismo, associações comerciais, lideranças religiosas e outros9. No santuário, e em seu entorno, em suas zonas concêntricas de irradiação, a complexa espacialidade do sagrado e do profano

\footnotetext{
${ }^{8}$ Sobre as peregrinações e interfaces com o turismo religioso, Carneiro (2004) realizou um estudo acerca de cinco caminhos da fé no Brasil. Há, também, um interessante estudo sobre o tema em Toniol \& Steil (2010).

${ }^{9}$ O Ministério do Esporte e Turismo, junto com a Cúria Metropolitana do Rio de Janeiro, publicou um catálogo "Roteiros da Fé Católica" nos anos 2000, com 75 roteiros de cerimônias religiosas no Brasil, lançado no 28 Congresso Brasileiro de Agências de Viagens, ocorrido em 2000, em Salvador. Os deslocamentos dos católicos brasileiros geraram, em 2000, mais de 9 milhões de reais em viagens por ano. Sobre isso, ver: ESTADÃO. Embratur lança "Roteiros da Fé Católica" Viagem, 14 set. 2000. Disponível em: <http://viagem.estadao.com.br/noticias/geral,embratur-lanca-roteiros-da-fe-catolica,20000914p14762>. Acesso em: 03 fev. 2018.
} 
ensejam múltiplos entrecruzamentos entre expressões religiosas, espirituais e mercadológicas (ROSENDHAL, 1996; 1999; 2003)

Um outro conceito fundamental na constituição dos deslocamentos turístico-religiosos contemporâneos é o de santuário. Os estudos clássicos de ciência, ou ciências, da religião, apontam para este aspecto fundamental: a fé religiosa, como ato individual ou coletivo, como processo ou identidade, está ligada às vivências territoriais e espaciais, destacando-se nela o santuário (ELIADE, 1992; EADE, SALLNOW, 1991; TURNER, 1974, 2008; TURNER, TURNER, 1978; STEIL, 1996). ${ }^{10}$

Para delimitar mais os arranjos deste texto, elejo, para apreciação, dois tipos de deslocamento: o que eu chamo de "turismo católico-carismático"11 - ou seja, os deslocamentos religioso-turísticos ${ }^{12}$ ligados ao movimento carismático católico (em Aparecida e em Cachoeira Paulista, no estado de São Paulo) 13 - e um turismo espiritual, ligado aos adeptos de novas espiritualidades, a um santuário pósmoderno, a pousada-spa-espaço espiritual Ashram-Vrajabhumi (em Teresópolis, na região serrana do Rio de Janeiro).

As teorias ${ }^{14}$ sobre os rituais ${ }^{15}$ e lugares católicos-carismáticos de grande fascínio - como a comunidade Canção Nova, em Cachoeira Paulista - descrevem os carismáticos como grupos e indivíduos dotados de uma identidade antissincrética, moderna, racional, baseada em uma ética rígida de valores, embora estivessem ligados às formações tradicionais - como a obediência ao poder pastoral e à moral conservadora (OLIVEIRA, 2007). A identidade dos católicos-carismáticos, em

\footnotetext{
${ }^{10}$ Steil (1996) nota que são muito poucos os estudos etnográficos sobre santuários no Brasil.

${ }^{11}$ Trata-se aqui não se um segmento de mercado, mas de uma categoria nascida da observação etnográfica em articulação com as teorias. Sabe-se que o turismo religioso, conforme apontado, é uma área em que se confundem muito categorias 'nativas" (oriundas do mercado, por exemplo) e categorias acadêmico-analíticas (OLIVEIRA, 2004; 2005; 2010).

${ }^{12}$ Optei por unir essas duas expressões por entender que se há um aspecto religioso nas romarias e peregrinações, esses deslocamentos religiosos possuem um aspecto turístico porque não podem mais ser separados, por exemplo, das redes socioeconômicas e midiáticas que se estendem em torno aos santuários (STEIL, 1996; WERNET, 1992).

${ }^{13}$ Fundada em 1978 pelo padre Jonas Abib e por um grupo de leigos católicos convertidos à Renovação Carismática Católica (RCC). Para informações, ver o website da comunidade Canção Nova, disponível em: <http://comunidade.cancaonova.com/>. Acesso em: 03 fev. 2018.

${ }^{14}$ Sobre isso, ver por exemplo, os trabalhos de Mariz e Machado (1994) e Prandi (1997), Oliveira (2007), entre outros.

${ }^{15}$ Considerando apenas a RCC, há, pelo Brasil, os festivais de música, encontros temáticos (cura e libertação, encontro para casais e famílias etc.) e a expansão das comunidades de vida e aliança, abrindo filiais pelo Brasil afora, e também pela Europa e pelos EUA.
} 
algumas teorias, seria forjada pelo contraste racional em relação às religiões de matriz africana/mediúnica e em relação às influências da Nova Era, todas vistas como demoníacas. Essas configurações religiosas constituem, aos olhos carismático-pentecostais, uma nebulosa figura de elementos heteróclitos que também incluiriam práticas de adivinhação, massagens holísticas, músicas new age, filmes, livros, oráculos chineses, viagens a lugares sob a influência do demônio. Percebi, durante as observações dos deslocamentos de indivíduos católicos-carismáticos e não-carismáticos aos santuários, que as explicações sociológicas subtraíam aspectos importantes dos processos simbólico-culturais que envolviam o consumo, a performance, o lúdico, e o irreverente; e que, por isso mesmo, indicavam uma aproximação fenomênica com o mundo espiritual Nova $\operatorname{Era}^{16}$.

De acordo com Eliade (1992), Eade e Sallnow (1992), Turner (1974, 2008) e Turner e Turner (1978), entre outros, os santuários são estruturas tempo-espaciais complexas e abertas à produção e recepção de diversos sentidos e significados por parte de um amplo e variado conjunto de grupos: os que detêm o controle institucional; os que administram o cotidiano do espaço sagrado, os que acorrem em romarias, peregrinações e turismo que, por sua vez, são diversos internamente, em relação a gênero, região, educação, adesão religiosa etc.

A relação entre todos esses grupos sedimenta-se historicamente a longo prazo e está sujeita a tensões e alianças (STEIL, 1996). Em geral, os controladores institucionais (sacerdotes e hierarquias) procuram impor a ortodoxia e o dogma aos visitadores; os que acorrem o santuário exercem sua adesão e identidade religiosas de formas muitas vezes heterodoxas e desviantes em relação ao padrão formal-oficial; os administradores buscam ser mediadores de forças em constante fricção (STEIL, 1996). O catolicismo, em alguns casos, "expande-se para além dos marcos dogmáticos e institucionais da Igreja Católica, podendo, ao mesmo tempo,

\footnotetext{
${ }^{16}$ Essas conversas e observações se deram quando viajei, em grupo ou sozinho, para participar de encontros e missas, em especial os realizados na Comunidade Canção Nova ou na cidade de Aparecida, um dos maiores santuários marianos do mundo. O local recebe cerca milhões de turistas ao ano, segundo os dados de 2015 do Ministério do Turismo.
} 
ter assegurada a sua continuidade a partir (...) da descontinuidade em relação à tradição e ortodoxia católicas" (TONIOL; STEIL, 2010, p. 3). Assim, "semelhanças e dessemelhanças, permanências e modificações no âmbito do catolicismo não necessariamente operam como práticas excludentes ou contraditórias, mas coexistem, contraditoriamente, em suas temporalidades diversas" (TONIOL; STEIL, 2010, p. 3).

O espaço santuarial é heterogêneo, composto de núcleos sucessivos, que o aproximam da hierofania ou do sagrado (achado de uma estátua, imagem, a recepção de uma profecia ou mensagem etc.) e as bordas, franjas ou periferias, que o distanciam do sagrado e o aproximam do profano, do dia-a-dia, do comércio e do consumo, do mercado (OLIVEIRA, Christian, 2004, 2005, 2010; OLIVEIRA, 2015). Os níveis de abrangência de um santuário, isto é, até onde se estende sua influência ou seu manto, podem ser internacionais, nacionais, regionais e locais (TURNER, TURNER, 1978; ROSENDHAL, 1999). Quanto maior a importância de um santuário, mais densas e complexas são as relações, sociais, religiosas, econômicas e espirituais. No caso deste texto, fiz pesquisas em dois locais em nível nacional-regional e local - e em uma trajetória - que, à primeira vista, pode não fazer sentido, de católicos-carismáticos à espiritualidade new age, mas há três linhas conectoras. Uma delas foi constituída pela trajetória dos sujeitos investigados, ${ }^{17}$ a proximidade semântica entre o universo carismático e o new-age e o arranjo metodológico com o pano-de-fundo da tensão entre turismo e religião.

Contudo, nos flashes etnográficos deste artigo, tomo, para discussão, parte do que transita nos círculos concêntricos que se espraiam entre a hierofania e a não-hierofania e acompanho apenas os grupos que acorrem aos santuários em fluxos mesclados (turismo, busca espiritual, religião) (ROSENDHAL, 2003; OLIVEIRA, 2005, SILVEIRA, 2004). E o que transita nos círculos? Corpos, afetos, memórias, indivíduos, grupos, consumo, seriedade, fé.

\footnotetext{
${ }^{17}$ A peregrinação ou romaria, assim como turismo, supõe um ritual e um trajeto: a preparação, a partida, o trajeto, o ápice, a preparação para a volta, o retorno. Darei enfoque ao intervalo entre a partida e o retorno. Há, nesse aspecto, as discussões teóricas sobre liminaridade (TURNER, 2008; EADE, SALLNOW, 1991), mas, por questões de espaço e estratégia metodológica, concentrar-me-ei nos relatos de campo e avaliações teóricas.
} 


\section{Os carismáticos no Santuário Nacional de Aparecida}

Apresento, portanto, o relato de uma pesquisa de campo $^{18}$, quando viajei com uma pequena caravana ${ }^{19}$ - eu, oito homens e quatro mulheres, membros do movimento carismático católico - que demonstra essas questões, em consonância com a bibliografia (STEIL, 2001, 2004; OLIVEIRA, 2003, CAMURÇA, 1998). Permaneci hospedado durante alguns dias em Aparecida, cidade que gira em torno do Santuário da Padroeira do Brasil, Nossa Senhora Aparecida, e que recebe em torno de 6 milhões de visitantes por ano, com milhares de leitos para romeiros, peregrinos e turistas - uma das maiores redes de hospedagem do Brasil. Fiquei em um quarto coletivo. Para participarem de eventos, como missas, seminários e shows, realizados em cidades próximas ou distantes entre si, e visitarem centros altamente atrativos, como a Canção Nova ou a Comunidade Shalom, os carismáticos hospedam-se ali2o. Tratava-se de um encontro de cura e libertação, ocorrido em 200o, de 19 a 22, voltado para a formação de líderes, com oficinas práticas, palestras, vivências, testemunhos e outros instrumentos pedagógicoespirituais.

Liderava o encontro de cura e libertação um padre indiano, chamado Rufus Pereira ${ }^{21}$, que em anos posteriores (1999-2012) tornara-se uma figura requisitada pela Comunidade Canção Nova, uma das potências do catolicismo carismático. Esse sacerdote integrava o conselho internacional da $\mathrm{RCC}^{22}$ e era reconhecido pela perícia em realizar exorcismos e libertações ${ }^{23}$. O evento reuniu em torno de dois

\footnotetext{
${ }^{18}$ A pesquisa ocorreu entre os anos de 1999 e 2002.

${ }^{19}$ De uma cidade de porte médio, da Zona da Mata, Minas Gerais, além da pequena caravana na qual estava, havia 30 outros carismáticos católicos que foram a esse evento. A cidade possuía, naquela época, cerca de 95 grupos de oração e um movimento carismático organizado. Uma associação fora criada para gerir problemas, mas conflitos e tensões permaneceram entre líderes e grupos.

${ }^{20}$ A sede da comunidade fica em Fortaleza, Ceará. Fundada nos anos 1980, é uma poderosa comunidade, com mais de 30 casas no Brasil e 10 no exterior.

${ }^{21}$ Faleceu em 2012. Há um website que fez uma compilação de palestras, bem como vídeos no YouTube, com algumas de suas pregações na Canção Nova. (Disponível em: <http://www.padrerufus.net.br/p/pregacoes-padre-rufus-pereira-periodo.html> Acesso em: 01 fev. 2018.)

${ }^{22}$ ICCRO é a sigla do escritório internacional da Renovação Carismática Católica.

${ }^{23}$ Apresentava-se como um dos poucos padres autorizados pelo Vaticano a realizar exorcismos. Veja-se um exemplo de pregação sobre cura e libertação em uma missa na Canção Nova, disponível em: <https://www.youtube.com/watch?v=IcdV90kOdwg>. Acesso em: 05 fev. 2018.
} 
mil líderes dedicados ao "ministério de cura e libertação²4, vindos de todas as regiões brasileiras. A programação do evento girou em torno de palestras, entremeadas de orações coletivas, missas, testemunhos e outros dispositivos pedagógico-espirituais. Esse encontro foi realizado em um dos prédios da arquidiocese, uma grande sala com um enorme palco. A partir de 2002, ergueram um shopping com muitas lojas e praça de alimentação ao lado da Basílica Nacional. Há a rede de televisão TV Aparecida, com abrangência nacional, além da Rádio Aparecida, dos anos 1930. O shopping nasceu de uma estratégia da Igreja, em aliança com o poder municipal e empresarial, para organizar o caótico e imenso comércio que se formou em torno do santuário. O Santuário Nacional tornou-se também um grande complexo turístico, comercial, religioso e midiático atrelado ao mítico centro do sagrado (ELIADE, 1992; 2002).

Antes de dirigir-me à missa de abertura, que seria feita na igreja do século XVIII'25 - o primeiro santuário dedicado à Virgem Aparecida, que logo ficou pequeno diante da afluência contínua de romeiros e peregrinos - visitei algumas lojas de produtos religiosos espalhadas pelas ruas da cidade ${ }^{26}$. Entrei com alguns curadores carismáticos em uma loja de artigos religiosos. Eles me cutucaram, dizendo em voz baixa: "Veja lá, a panela da fartura, coisa de crendice, precisa cuidado pra não se contaminar”. A panela da fartura da qual falavam é uma pequena cumbuca de barro com cereais (arroz, feijão e sementes plastificados), com uma imagem da padroeira do Brasil. Depois, outro carismático sussurrou: “mas aqui não é uma loja católica? O que aquelas imagens de Preto-Velho, Iemanjá

\footnotetext{
${ }^{24}$ Ministério de Cura e Libertação foi o nome dado às atividades ligadas às orações de cura e libertação nos grupos de oração, encontros e seminários de formação da "mão-de-obra" carismática.

${ }^{25}$ A devoção à Nossa Senhora Aparecida nasceu em 1717, quando uma imagem foi achada no rio Paraíba, primeiro a cabeça, depois o corpo. A população narrou milagres alcançados, atraindo, ao longo dos anos, milhares de romeiros e peregrinos. A história do santuário nacional é longa demais para se detalhar nos limites desse artigo, mas, por exemplo, envolve dois santuários ligados por uma passarela, o antigo, do século XVIII, e o novo, dos anos 1960. (FERNANDES, 1988).

${ }^{26}$ Por questões de espaço, não aprofundarei a relação dos santuários com o comércio. O peso econômico do santuário pode ser enorme, como em Aparecida. Sobre as lojas de produtos religiosos que visitei, vislumbro uma tipologia: lojas oficiais, ligadas aos administradores, e lojas não-oficiais. Nestas, há uma diversidade enorme: lojas apenas com produtos católicos e lojas mescladas, que vendem uma profusão de expressões religiosas e espirituais que vão dos católicos às entidades da umbanda, candomblé e do universo new age.
} 
e Nova Era $^{27}$ fazem meio escondidinhas ali?” Saíram da loja, então. Alguns deles oravam.

Fomos à missa no santuário antigo: lotada, longa, demorada e abafada. $\mathrm{O}$ barroco do altar e da arquitetura pareciam deslocados em uma liturgia que mesclava o ritual romano de Paulo VI (promulgado em 1969), com cantos, êxtases, glossolalias e profecias dita em voz alta. O Padre Rufus Pereira, traduzido do inglês por um intérprete voluntário, fazia um discurso cheio de referências ao amor de Deus que "a tudo cura”, “corações, corpos e mentes quebradas"; segundo o sacerdote indiano, "restaura o que se partiu" e "vai ao fundo da alma"; imagens de integridade, autenticidade e transcendência. Uma outra fala do padre me chamou a atenção: "a cura da alma e a cura interior são um processo para a vida toda, para serem buscadas a toda hora, pois sempre teremos de ser amados e curados para amar e transmitir a cura que vem de Deus e somente dele”. Há proximidade entre as sensibilidades carismáticas e as nova-eristas (STEIL, 2004; OLIVEIRA, 2003). O movimento carismático católico, ao mesmo tempo em que reteria os católicos na Igreja, possibilitaria um deslocamento das formas tradicionais da identidade católica para formas mais individualistas e/ou reflexivas. O que também possibilita essas entradas/saídas são, justamente, os deslocamentos e circulações que envolvem as vivências em santuários geográfico-turísticos.

Sobre a Nova Era, Amaral (2000; 2003) fala que o modelo xamânico adquiriu a hegemonia e situa-se próximo das sensibilidades católico-carismáticas (OLIVEIRA, 2003; STEIL, 2004). A ideia de cura interior e libertação como um processo espiritual incompleto e incessante está próxima do discurso da Nova Era. Há um processo por meio do qual o sujeito busca seu self ou deixa-se restaurar e inundar-se, para transbordar ao mundo, por forças transcendentais ou cósmicas, em uma totalidade que o ultrapassa e da qual é uma ínfima parte, uma totalidade

\footnotetext{
${ }^{27}$ Descobri que a pessoa se referia a pequenas imagens de gnomos e fadas. No imaginário carismático, esses seres pertencem à Nova Era, uma "conspiração demoníaca" contra o cristianismo.
} 
reencontrada (CSORDAS, 1997). E a busca de eventos e santuários para viver essas tecnologias de cura é uma constante entre carismáticos e nova-eristas.

Na pequena pousada onde me hospedei, os carismáticos não me deixavam sossegado para redigir o diário de campo: à noite, chamavam-me para orar e praticar as orações e os ensinamentos dados ao longo do dia. Durante uma dessas reuniões, em um dos quartos do hotel, formamos um círculo; as mãos foram, então, impostas uns nos outros (nos ombros, na cabeça, no coração). Éramos seis pessoas de mãos dadas, quatro homens e duas mulheres. De repente, alguém soltou as mãos, começou a orar em línguas - a glossolalia, uma linguagem de sons, que pode ser cantada também, sem significados e morfologia racionais - uma performance verbal virtuosa. Senti uma sensação de estupor e me assustei. Um silêncio abateuse sobre o ambiente. Instantes depois, alguém afirmava, categoricamente, que Jesus estava ali, vestes longas e brancas, barbas negras, mãos ensanguentadas, tirando de nós as “contaminações espirituais” ${ }^{28}$. Os modos de ser carismáticocatólico brotavam o tempo todo no evento: a glossolalia, as revelações - ou seja, palavras, imagens e emoções ditadas pelo Espírito Santo para mostrar coisas ocultas, dar uma ordem para curar, libertar, orientar; as curas, sejam elas físicas, mentais ou emocionais; as profecias - ordens, conselhos e expressões vindas de Deus, transmitidas, vocalmente, em primeira pessoa; e os repousos no espírito (CARRANZA, 2000; OLIVEIRA, 2003) ${ }^{29}$.

A atmosfera do evento como um todo, era descrita assim pelos homens e mulheres que entrevistei30: "pisar em nuvens”, "esbarrar em anjos”, "ser acariciado por Deus", “experimentar o colo de mãe”, “estar em um jardim místico”, "dançar com santos e Nossa Senhora”, “ouvir sons inefáveis”, "sentir forças poderosas que vêm de Deus no fundo do ser", "sentir o doce perfume do amor materno", "sentir os dedos de Deus arrancando angústias do peito", "um novo nascimento”, "um

\footnotetext{
${ }^{28}$ A ideia de contaminação presta-se a diferentes semânticas, conforme contexto, local e pessoas envolvidas.

${ }^{29} \mathrm{O}$ repouso no Espírito é um desfalecimento corporal que ocorre em oração. Estudo sobre a fenomenologia da cura carismática foi realizada por Csordas (1997).

${ }^{30}$ Expressões ditas pelos participantes nos variados momentos de conversa e de entrevistas durante o intervalo entre as intensas atividades do seminário.
} 
interior em processo de renovação contínua”, “águas puras lavando o espírito”, “um novo homem nascendo" etc. 31

Componente comum nos encontros de cura e libertação são as tecnologias corporais: abraços, imposição de mãos, toques, silêncios, danças, etc. (MAUÉS, 2003). A densidade ontológica carismática está, paradoxalmente, próxima da densidade fenomênica da Nova Era. No imaginário católico, a lógica é a de uma “arte da inclusão”: “(...) integra uma variedade de formas e valores que poderiam ser, em outros contextos, radicalmente separados”. (FERNANDES, 1988, p. 97). É uma dinâmica parecida com a da Nova Era, que inclui elementos de outras tradições, atravessada por uma lógica que descanoniza e dessubstancializa, liberando pontos de fuga. É o oposto da força centrípeta católica, que recria centros estáveis, justapondo ou fundindo elementos diversos.

Pela manhã, no segundo dia do evento, após a palestra sobre libertação e exorcismo, estava ao meu lado uma curadora carismática de Minas Gerais, com cerca de sessenta anos de idade e dez anos de prática no ministério de cura e libertação. Mirando-me, lançou um olhar incrédulo quando o Padre Rufus Pereira criticou a acupuntura e as terapias complementares, porque essas seriam um pacto demoníaco, porquanto provenientes de doutrinas não-cristãs e reencarnacionistas. “Esse padre hindu está errado!”, exclamou a senhora com surpresa, em voz baixa, esperando alguma cumplicidade em meu olhar. Perguntei o porquê do espanto, ao que ela respondeu: "Eu estava ruim da coluna há dois anos e fiz acupuntura. Não senti mais nada depois. Li livros, procurei saber, orei e pedi discernimento a Deus, e ele me disse que o que importa é a intenção”.

Segundo a carismática, "Deus mostrou-me que pode tudo, pode fazer ou produzir luz das trevas e sempre trago isso em meu coração”. Maior surpresa, ainda, causaram as narrativas sobre os exorcismos feitos em aldeias rurais na

\footnotetext{
${ }^{31}$ O tema do novo homem e da nova mulher é constante, com diversos sentidos que aproximam a espiritualidade carismática de formas mais nova-eristas (OLIVEIRA, 2003; D'ANDREA, 2000).
} 
Índia. Entre elas, estavam a de um homem possuído pelo Diabo que grudou no teto, ou a de uma árvore que ficou cheia de demônios expulsos de uma mulher idosa, invisíveis aos olhos comuns, mas prontos para atacar cristãos-católicos que reverenciassem deuses hindus ou algum altar a eles dedicados - segundo o discurso do sacerdote exorcista indiano.

Quase que paradoxalmente, em uma das palestras da segunda manhã, o padre Rufus Pereira disse: “todas as religiões, no fundo, querem chegar a Deus”. E continuou: "Há tanta gente quebrada no corpo, na alma e no espírito, armas de destruição em massa, genocídios, e, por isso, procuram soluções e religiões que não resolvem”. Então, "as soluções verdadeiras surgem pelo cristianismo, com sua singularidade absoluta, ou seja, Deus é pessoa, somos pessoas e Ele quer ter um relacionamento pessoal conosco". Há, ainda, um “amor tão radical que se nós não correspondermos às expectativas, com os outros ou conosco, se fracassarmos, Deus sempre perdoará, dará sempre chances de recomeçar”. Seu falar era bem vagaroso, quase ditando para o tradutor: "Jesus pregava e curava a toda hora, e a síntese de sua mensagem é que Deus nos criou por amor, para sermos como Ele, para sermos felizes. Criou-nos para fazer parte de sua vida divina, e ele quer que cada um de nós seja melhor".

Durante os intervalos do evento, mercadoria e consumo estavam presentes: nos "verbos midiáticos" encarnados - livros sobre cura, libertação, exorcismos, CDs, DVDs; terços dos mais diversos tipos, tamanhos, cores (terço da cura interior, terço da misericórdia etc.), objetos religiosos, camisas e outros. Nos pequenos estandes montados na entrada do auditório, havia a presença dos "produtos Canção Nova”, um elemento essencial do catolicismo carismático e do turismo religioso católico.

Um tempo depois, desse evento, o padre exorcista rumou para o "Rincão do Meu Senhor”, um local na comunidade Canção Nova com capacidade para acomodar quatro mil pessoas. Lá, visitei o local dos acampamentos, conversei com 
jovens acampados ${ }^{32}$ e outros que vieram participar da missa e das palestras. A comunidade carismática tinha um enorme terreno, com galpões, onde se realizavam os encontros e missas, e outros prédios, com um espaço para a prática do camping dos peregrinos, romeiros e turistas - o que deu origem ao nome de um dos eventos mais populares, os Acampamentos, com temas variados. Possuía, ainda, uma rádio, que atingia boa parte do Brasil. Nos anos seguintes, essa estrutura expandiu-se e as fronteiras entre peregrinação, romaria e turismo indeterminaram-se.

A Canção Nova criou uma rede de televisão com programação e abrangência nacional e internacional. Desde 2004, mantém um Portal Eletrônico com milhares de acessos e possui trinta núcleos e casas no Brasil, além de estar em países como Itália, Israel, França, EUA (países nos quais totalizam oito núcleos) (OLIVEIRA, 2015). Possui, segundo dados de 2015, 671 mil sócios, 672 missionários integralmente dedicados (moram e vivem na sede e nas filiais) e 401 missionários com dedicação parcial (OLIVEIRA, 2015) ${ }^{33}$. Atualmente, a sede da Canção Nova34 conta com o Centro de Evangelização Dom João Hipólito de Moraes (70 mil pessoas); o Santuário Pai das Misericórdias (10 mil pessoas); o Rincão do Meu Senhor (4 mil pessoas); o Auditório São Paulo (para 700 pessoas)35. No espaço do terreno, há diversas capelas, posto médico, escola, restaurante, padaria, postos bancários, lojas de artigos religiosos, pousada, área de camping e, no entorno, prédios administrativos e obras sociais ${ }^{36}$ (OLIVEIRA, 2015).

A pousada da comunidade recebe dezenas de hóspedes. Há, inclusive, um setor responsável por fazer viagens, oferecendo pacotes e direção espiritual a cargo

\footnotetext{
32 Essa prática começou nos anos 1990, em que famílias e jovens traziam barracas para acampar durante os eventos. Nesse evento específico, a maioria dos 400 acampados tinha entre 18 e 25 anos.

${ }^{33}$ Existem movimentos criados pela própria comunidade, como o PHN-Por Hoje Não vou Mais Pecar, voltado para jovens e liderado por Dunga, pop-star da Canção Nova. Reúne milhares de jovens em um evento com o mesmo nome, realizado na Canção Nova. $O$ discurso é voltado para a busca de uma vida guiada por padrões morais, como o namoro santo, sem relações sexuais antes do casamento, casamento sem anticoncepcionais (apenas métodos naturais) etc.

${ }^{34} \mathrm{O}$ terreno tem, ao todo, mais de 360 mil metros quadrados.

35 Há grandes eventos, como o Festival Hosana Brasil (música, cantores e bandas), com mais de 15 mil pessoas anualmente (novembro/dezembro). Há um calendário extenso de eventos, além do litúrgico da Igreja Católica.

${ }^{36}$ Dados e informações estão disponíveis em: <http://comunidade.cancaonova.com/quem-somos/linha-do-tempo/> Acesso em: 03 fev. 2018.
} 
de sacerdotes e dos líderes mais experientes da comunidade. Os destinos variam dos santuários marianos na Europa à Terra Santa, em Jerusalém37. O "turismo católico-carismático" provocou a expansão da rede hoteleira da cidade de Cachoeira Paulista, onde a comunidade Canção Nova está situada. Segundo dados da prefeitura, a cidade de Cachoeira Paulista recebe, anualmente, um milhão de visitantes, muitos deles peregrinos, turistas e romeiros que se dirigem à Canção Nova (OLIVEIRA, 2015).

Segundo os moradores, antes havia poucos hotéis e pousadas, mas hoje há muito mais. Há, por exemplo, a pousada São João Batista, que mantém sites, com um link intitulado "Agenda Canção Nova” (com todas as datas dos eventos, mês a mês) ${ }^{38}$, e anúncios: "venha para Canção Nova e Circuito Turístico Religioso e reserve sua estadia conosco!”; "Santuário Pai Das Misericórdias. A Pousada São João Batista está a 940 metros da Canção Nova. Venha Nos Conhecer!"; "Venha para Canção Nova. Temos vagas para vários acampamentos”. Reparei que nessa pousada, a sala de recepção é católica: um quadro com a imagem do sagrado coração de Jesus e de Maria, um pequeno nicho no canto da parede com várias imagens: Santa Terezinha do Menino Jesus, São Miguel e Nossa Senhora Aparecida.39 A Canção Nova, em outras palavras, é um complexo espiritualturístico-empresarial-midiático, é uma hierápolis, cidade sagrada, com hierarquias e estruturas que efetivam a gestão administrativo-espiritual (OLIVEIRA, 2015).

\section{Turismo espiritual na região serrana}

De que forma abordar um mundo espiritual, sem solidez, existente nas entrelinhas e interstícios das relações sociais e que se recusa a ser uma ordem ontológico-definitiva, dogmática-gloriosa ou fixa-institucional?

\footnotetext{
${ }^{37}$ Dados disponíveis em: <http://blog.cancaonova.com/peregrinacoes/>. Acesso em: 03 fev. 2018. A Canção Nova associou-se a outra comunidade religiosa, chamada Obra de Maria, dedicada, exclusivamente, a proporcionar viagens "espiritualizadas" a peregrinos. Possui 30 casas espalhadas pelo Brasil. Mais detalhes estão disponíveis em: <http://www.obrademaria peregrinacoes.com/site/quemsomos>. Acesso em: 03 fev. 2018

${ }^{38}$ Disponível em: <http://www.pousadasaojoaobatista.com.br/site/agenda-cancao-nova/>.Acesso em: 04 fev. 2018.

${ }^{39} \mathrm{O}$ circuito turístico religioso envolve, além da Canção Nova, a cidade e o Santuário de Aparecida e a cidade de Guaratinguetá, onde está o santuário de Frei Galvão.
} 
As questões relativas às fronteiras das identidades e seus contornos radiais, rizomáticos, atormentam os pesquisadores do mundo Nova Era40. Pode-se entrar nesse mundo, portanto, através de qualquer trilha. Por isso, um resultado da indeterminação de fronteiras religiosas na bibliografia mundial são as variedades de descrição empírica e formulação teórica que vão desde uma metapragmática reflexivista nova-erista - contaminando e transformando diversos sistemas e tradições, até grupos que não são propriamente Nova Era ${ }^{41}$ - tais como as seitas mágico-milenaristas e ufológicas, por exemplo, que pode, reagir, fechando-se e procurando identidades mais fixas e peso ontológico.

Segundo a literatura acadêmica, há uma oscilação entre duas lógicas e estruturas espirituais-religiosas: uma Nova Era assentada em uma lógica póstradicional, cujo símbolo seria a busca de um self-shaping autorreflexivo, que abre caminhos para incessantes hibridismos; e uma Nova Era assentada em uma lógica fundamentalista, mágica e tradicionalista, cujo epítome são as seitas high-tech, como a Heaven's Gate, organizadas em torno de ideias milenaristas, mágicas e sobrenaturais, que enclausuram o círculo das livre-experimentações (D’ANDREA, 2000).

Há duas polaridades que formatam o amplo espectro nova-erista: comunidades alternativas, centros holísticos e outros lugares que catapultam o consumo (produção/oferta de livros, objetos, palestras, vivências, workshops e outros); e o fluxo itinerante de indivíduos, experimentadores, terapeutas, profissionais, xamãs urbanos, gurus neomodernos, facilitadores de workshops, lideranças espirituais que compram, vendem e usufruem de bens e serviços ligados a esse extenso caleidoscópio religioso e aceleram o deslocamento espiritualturístico (MAGNANI, 1999a; 1999b). O mundo Nova Era seria um

\footnotetext{
${ }^{40}$ Definir a Nova Era é uma tarefa complexa e extrapola este texto. Do rastro da contracultura - as revoltas estudantis e trabalhistas de 1968, o festival de Woodstock, em 1969, as novas e famosas bandas de rock e sua relação com religiosidades orientais, como o hinduísmo -, emergiam produtos e serviços voltados para um público de classe média alta urbana que aspirava um novo estilo de vida: livros, terapias corporais (massagens, yoga tântrica e outros), ressignificação de práticas antigas (astrologia, tarô e outras), workshops de terapia alternativa, e que começam a difundir-se dos grandes centros mundiais (Londres, Nova York, Los Angeles) para cidades e localidades ao redor do mundo.

${ }^{41}$ Sobre isso: Carozzi (1999; 2000), Amaral (2000), Hanegraaff (1996) e outros.
} 
campo de experiências e articulações momentâneas, provisórias e efêmeras que inclui uma gama de pessoas diferenciadas e que apresenta, em seu campo de atividades, o cruzamento de áreas tão diversas da vida como o negócio, o lazer, o esporte, a ecologia, a medicina, a ciência etc. (AMARAL, 2003, p. 47).

Sob esta perspectiva, a nebulosa Nova Era é constituída por “comunidades evanescentes", formadas em tempos e espaços no mundo urbano e no rural (comunidades rurais que se retiram do mundo, fundam outras existências).

Deparei-me com esse mundo ao visitar um complexo hotel-fazendapousada-spa-espiritual, o Ashram42 Vrajabhumi, na estrada para Teresópolis43, e que expressa toda a tipicidade Nova Era, embora ligado a uma religiosidade hinduísta, no caso o movimento Hare Krishna44.

Um santuário "pós-moderno", se assim posso me referir a essa estranha mistura de espaço turístico e espiritual. É um lugar cada vez mais famoso e frequentado por homens e mulheres de classe média e alta do sudeste urbano. Entretanto, pode-se levantar a objeção metodológica de apresentação de comunidades vaishnava como novaeristas no presente texto. Mas defendo a existência de ao menos três condicionantes de novaerização: mercado e consumo modernos, desterritorialização de crenças e práticas de seus solos originais e sua oferta como serviço, integrada a um formato turístico (SILVEIRA, 2015 a; 2015, b). 45

Ao fim dos anos 2000, retornei ao Ashram-Vrajabhumi, que inicialmente era uma comunidade ortodoxa, pouco aberta ao mercado e ao consumo, acompanhando uma caravana de oito pessoas, depois de comprar um pacote espiritual com meditação e vivências ou workshops nova-eristas. A abertura da

\footnotetext{
${ }^{42} \mathrm{Na}$ antiga Índia, era um lugar nas florestas, onde os iogues e gurus viviam, buscando a iluminação. Hoje, o termo designa uma comunidade formada com o intuito de promover a evolução espiritual dos seus membros e orientado por um místico ou líder religioso, ou então um lugar de práticas espirituais, restritas ou abertas, mantido por um agrupamento religioso de cunho oriental ou hindu.

${ }^{43}$ Estrada Teresópolis-Friburgo, quilômetro 6,5, Rio de Janeiro. O complexo é constituído, atualmente, pelo Hotel Fazenda Gaura Mandir Vrajabhumi e pela pousada/spa Vrindavana.

${ }^{44}$ Para uma apresentação inicial no Brasil, ver Guerriero (2001).

${ }^{45}$ Não poderei adentrar aqui, por força do espaço, as polêmicas classificatórias que envolvem comunidades vaishnava e ashrams como - Vrajabhumi, e outras A necessidade de recrutar novos membros afeta desigualmente os processos de gerenciamento das relações sociais internas a essas comunidades (ADAMI, 2013).
} 
comunidade ao público não-devoto e ao mercado turístico ocorreu depois de uma crise, pouco antes de 2000, que quase fechou o lugar. Os fundadores buscavam novas formas de manter a pousada viva, mas isso implicou em uma transformação new age. O tema das comunidades religiosas orientais no Brasil e no mundo é amplo e complexo e relaciona-se à poderosas forças de desterritorialização e reterritorialização em âmbito global e local que transformam, profundamente, lugares, valores, símbolos e propostas (ADAMI, 2013).

Interessava-me, por essa época, acompanhar como alguns sujeitos católicocarismáticos deslizavam por entre mundos aparentemente inconciliáveis. ${ }^{6} \mathrm{Um}$ deles era o que chamei de curador flutuante, uma categoria que emergiu de meu trabalho de campo e que corresponderia a indivíduos que frequentaram os ministérios de cura e libertação, exerciam os carismas de forma mais ou menos autônoma, não se ligando institucionalmente aos grupos, comunidades e paróquias em questão, perambulando e realizando orações de cura, libertações e exorcismos.

A caravana foi conduzida por um casal de meia-idade, praticantes de yoga e estudiosos do hinduísmo, como se definiam à época, residentes de Juiz de Fora. Acompanhei essa romaria esotérica com outros homens e mulheres, todos com mais de 20 anos, em sua maioria "católicos" (com pouca prática ou apenas batizados; um deles, o curador-flutuante, definiu-se como um católico carismático de "mente aberta" que identifiquei na viagem). Foi um fim de semana cinestésico: incensos, massagens, caminhadas, aromas (alecrim, alfazema e outros), meditações e vivências, como são chamados os exercícios performáticos nova-eristas, similares às fenomenologias que correm em eventos carismáticos. Soube, depois, que o casal de instrutores, um empresário e uma advogada, foram batizados na Igreja Católica, mas haviam deixado o catolicismo e uma vida urbana agitada; ao longo do tempo, formaram-se, viajando para aprender espiritualidades.

\footnotetext{
${ }^{46}$ Interessei-me em participar desse encontro porque descobri, entre os participantes, uma mulher que havia frequentado um grupo carismático e participado do encontro com o padre exorcista hindu.
} 
O discurso de ambos rejeitava o termo religião e adotava o termo espiritualidade. Estiveram em São Paulo, em uma "escola xamânica", na Índia e no Nepal, além do Equador, onde viveram alguns meses entre indígenas para aprender "magias xamânicas, com a finalidade de desenvolver o espiritual que está latente na maioria das pessoas", segundo a fala da própria advogada.

Na manhã dominical, ocorreu uma performance de sobrecarga sensórioemocional, conduzido pelo casal, feito após um longo exercício de meditação. Com a ideia de "desamarrar os nós do ego, as cordas sociais, as máscaras que o sufocam", para descobrir a "profundidade do humano-cósmico dentro", e lá "encontrar o eu verdadeiro", palavras do casal instrutor, cada participante deveria escolher um colega para abraçar e tocar com suavidade e leveza, como se plumas fôssemos, segundo as instruções. A expressão "desamarrar os nós" é similar à noção de libertação usada entre os carismáticos, e significa, no caso nova-erista, libertar-se dos condicionantes sociais (repressão familiar e social) para encontrar um eu mais profundo, o autêntico self, em um processo interminável, recomeçando a cada seminário ou vivência (AMARAL, 2003).

Após o exercício do toque, conduziu-se uma visualização criativa, instigando os participantes a formarem imagens mentais, auxiliados pelos olhos fechados, incenso aromático e música instrumental. Alguns comandos foram emitidos, tais como: "Imaginem mil budas dourados saindo pelos poros, olhos, nariz, por cada parte do seu corpo"; "imaginem cada chacra do seu corpo sendo purificado, aberto, imaginem um fogo azul entrando pelo primeiro chacra e saindo pelo último".

Sentados em uma almofada, cada um externou a raiva, dor ou frustração sentida, de acordo com uma linha do tempo, iniciada no momento da gestação. A cada "etapa" da vida, os instrutores pausavam: "quando estavas no útero de sua mãe", "quando eras um bebê recém-nascido", "quando tinhas entre um e três anos de vida", etc. Houve choro convulsivo, murros em almofadas, gritos, gargalhadas guturais intermináveis e outras descargas sensoriais intensas. É interessante perceber que essa tecnologia sensório-corporal é similar à noção e à prática de cura 
interior dos carismáticos católicos que fazem uso de visualizações biográficas percorrendo os estágios da vida -, a partir de figuras da tradição cristã-católica, Jesus, Virgem Maria, anjos e santos47.

Toda essa conjugação das sensações e emoções, evidencia alguma desconfiança do intelecto, do racional e do sujeito como centro irradiador de uma razão instrumental e fria. Depois da sobrecarga emocional, mais meditação com yoga para, segundo os instrutores, "buscar o eu profundo, onde dorme o cosmo (...), o cosmos está em você, atravessa você, respira em você, age em você”. O “clima espiritual", como o descreveram os participantes do evento, foi comentado nos intervalos: "encontrei dentro de mim a beleza cósmica que faltava"; "senti fluir uma energia espiritual tão grande pelo meu ser, parecia um pequeno sol dentro do peito"; "era como se muros velhos e esburacados estivessem caindo e um jardim florido se abrindo ante meus olhos"; "fui tomada por uma sensação intensa de calor, senti-me aquecida e, como um metal incandescente, senti que brilhava"; "redescobri a mim mesmo"; "do fundo do abismo eu vi uma luz vibrante e espiritual que subia sem cessar", entre outras frases. Terminado o evento, o grupo dispersou-se, mas eu acompanhei o curador flutuante em suas andanças e experimentações.

Desde 2006, quando lá estive pela segunda vez, o hotel-fazenda-pousadaspa sofisticou-se. Oferece, hoje, pacotes com meditação no templo e atividades lúdico-espirituais em locais cheios de simbologias hindus48. Recebem grupos espiritualistas e promovem workshops, encontros holísticos, cursos e vivências49.

\footnotetext{
${ }^{47}$ Esta oração está disponível no portal da Comunidade Canção Nova: “Senhor Jesus, precisamos muito de Ti e de Tuas graças desde a nossa concepção, pois, depois de adultos, percebemos muitos sofrimentos em nós, os quais começaram antes mesmo da nossa fecundação. (...). Hoje, pedimos-Te, Senhor, que Teu Sangue lave a genética vinda de nossos pais, lave toda contaminação espiritual, todas as doenças e maldições, todos os problemas de rejeição e sofrimentos, tudo que nossa mãe absorveu com relação a vícios, brigas, abandonos, violências, desrespeitos e demais coisas que possamos ter enfrentado durante os nove meses de gestação. (...)". Disponível em: <http://formacao.cancaonova.com/espiritualidade/oracao/oracao-de-cura-interior-pelas-etapas-da-vida/>. Acesso em: 05 dez. 2017.

${ }^{48}$ O spa holístico oferece massagens e banhos, descritos em página eletrônica. Veja: "Massagem Aromaterapêutica Ayurvédica - R\$̦ 150,00. Ajuda o relaxamento neuromuscular, melhora a circulação sanguínea e linfática proporcionando profundo bem-estar físico e mental. (...). Associada ao Shiatsu, técnica de massagem oriental, que libera o fluxo da energia vital percorrendo os canais do corpo, prevenindo doenças, desenvolvendo equilíbrio e harmonizando o funcionamento orgânico.". Fonte: <http://vraja.com.br/spaholistico/>. Acesso em: 05 fev. 2018.

${ }^{49}$ Veja no link: <http://vraja.com.br/receptivo-de-grupos/>. Acesso em: 05 dez. 2017.
} 
Vendem-se três pacotes: o pacote Shiva50 (Terapêutico), o Krishna (Romântico)51 e o Ganesha5² (Fim de Semana), referência direta a nomes de deidades hindus. Com a duração entre dois e três dias, esses pacotes contêm um conjunto de serviços e produtos mágico-místicos e terapêuticos, alguns do quais com cerimônias no templo dentro do conjunto empresarial-terapêutico-espiritual.

$\mathrm{Na}$ origem dessa fazenda-spa-hotel, a ligação com a espiritualidade novaerista pode ser inferida:

Foram 25 anos de dedicação de Sergio Leite Pereira [...]. De playboy de Copacabana a Brâmane Hindu, estudioso da filosofia védica, alcançou nesta vida o título de Sriman Satru Koti Vinasana que o elevou à categoria de um homem evoluído espiritualmente. Dando prosseguimento ao trabalho de seu pai [...], o economista [...] e carioca Ricardo Leite Pereira, também iniciado espiritualmente como Radha Raman, administra hoje a pousada, ampliando o potencial holístico único de Vrindávana, sem perder o espírito empresarial (...)53.

Na narrativa oficial acima, aparece a mistura de dois pólos Nova-Era, o do poder-dinheiro e o da sabedoria-amor, que integram esse universo de vivências espirituais. Em outro texto de apresentação, lê-se o seguinte:

No topo das montanhas da Serra dos Órgãos em Teresópolis, está resguardado este paraíso de beleza natural ímpar, onde se encontram pessoas especiais de diferentes lugares. São naturalistas, esotéricos, casais namorados, espiritualistas e, claro, os amantes da natureza. Em um santuário ecológico, desde os anos 1970, oferecemos uma proposta de lazer única e confortável. Reunimos a temática indiana ao ecoturismo e às terapias holísticas, em uma Pousada e Spa pioneiros do circuito turístico [grifos meus]54.

Assim, foi durante esse fim-de-semana que conheci uma autodenominada bruxa wicca, jovem adulta (30 anos) cuja trajetória singular recuperei a partir de

\footnotetext{
${ }^{50}$ O pacote Shiva inclui pensão completa, massagem shiatsu com alongamento, quiropraxia, banho de Eros \& Afrodite (1 banho casal ou individual), massagem ayurvédica abhyanga, tratamento facial com máscaras revitalizantes, escalda-pés com reflexologia, bhakti yoga no Ashram (cerimônias no templo). O preço varia dentre $\mathrm{R} \$ 1.500,00$ e $\mathrm{R} \$ 2.500,00$. Link: http://vraja.com.br/shiva/.

${ }_{51}$ O pacote inclui pensão completa, fondue de chocolate, massagem Abhyanga ou shiatsu para casal, banho Eros \& Afrodite no ofurô panorâmico, preparação do quarto com pétalas de rosas, lazer da pousada, eventos no templo indiano (palestras, cerimônia e meditação). O preço é de R\$1.700,00. Disponível em: http://vraja.com.br/krishna/. Acesso em: 05 fev. 2018.

52 É o pacote mais barato, variando entre $\mathrm{R} \$ 790,00$ e $\mathrm{R} \$ 1.100,00$, com pensão completa, caminhada temática, lazer da pousada, eventos no templo indiano (palestras, cerimônia e meditação) e alimentação caseira vegetariana. Veja em: <http://vraja.com.br/ganesha/> Acesso em: 05 fev. 2018.

${ }^{53}$ Informações disponíveis em: <http://vraja.com.br/vrindavana/>. Acesso em: 05 fev. 2018.

${ }^{54}$ Informações disponíveis em: <http://vraja.com.br/vrindavana/ > Acesso em: 05 fev. 2018.
} 
antigas conversas anotadas nos diários de campo. Nascida católica, frequentou a RCC quando adolescente, mas, ao entrar para uma faculdade particular a fim de cursar turismo, abandonou as práticas católicas e começou a experimentar outras religiosidades, ou melhor, segundo sua própria fala: “abri-me ao mundo espiritual”. A viagem à pousada "oriental-hindu" no território fluminense fora mais uma das muitas viagens que realizou depois de encontrar seu "eu mais profundo e espiritual". (COSTA, 2004). A ideia de "encontrar-se" é uma tônica nos discursos nova-eristas e é muito próxima das narrativas de “conversões carismáticas”, nas quais enfatiza-se o encontro pessoal com a divindade, com Jesus e com o Espírito Santo.

Durante todo o evento, o casal reservou a sala de meditação da pousada-spasantuário e lá depositou alguns itens que consideravam sagrados durante suas viagens de iniciação xamânica. Apenas eles e os “iniciados” 55 podiam entrar para fazer os exercícios espirituais. Havia segredo e mistério. O lugar tornou-se, provisoriamente a imago mundi (ELIADE, 1992).

Ao final do encontro, os comentários dos participantes giravam em torno do clima fenomênico criado: "vibrações intensas que desfizeram meu eu antigo"; “sensação de ser bombardeado por raios espirituais poderosos que abriam meu peito encouraçado"; "foi como descobrir um túnel antigo, escuro, apertado, mas, ao final, com um tesouro"; "senti como se estivesse sendo desamarrado de cordas grossas e apertadas"; "reencontro comigo mesma", e outras narrativas. Após esse ritual, o grupo se desfez, e cada participante continuou adiante, no fluxo de sua rede de relações religiosas e espirituais. Uma interminável jornada aberta de busca espiritual que contrasta com a jornada cíclica dos carismáticos católicos em busca de confirmações espirituais.

\footnotetext{
${ }^{55}$ Pessoas ou indivíduos que, ao se filiarem a um grupo religioso, passam por um ritual de iniciação. A partir desse momento, começam a partilhar dos "segredos" e ensinamentos que, em tese, os não-iniciados não podem ter acesso.
} 


\section{Considerações finais}

O fluxo entre identidade - substantivação, afirmação de cânones e pertenças, primado de regras e contextos - e identificação - não-substantivação, desafirmação de cânones e pertenças, livre experimentação - é um movimento de vaivém. O que chama atenção no turismo católico-carismático e na Nova Era são as ideias de nova consciência, de reencontro com o divino, acesso às novas realidades do ser, do eu, do cosmo, do divino; redescobertas do sagrado transcendente, ultrapassagens de fronteiras, inner-self e outros elementos que ilustram o mergulho no sentido de ressignificar e ressemantizar conhecimentos, práticas, rituais e cosmologias em novos contextos urbanos - ou, ao contrário, para redescobrir identidades gastas, esgarças, dando-lhes, então, peso, gravidade e intensidade. Os santuários acabam por oscilar entre uma integridade-unicidade (fé) e uma não-integridade/não-unicidade (turismo).

Os navegantes new age estão em busca de uma transformação contínua do self, sentindo-se penetrados "pelo pleno potencial de vida" (AMARAL, 2003, p. 48), o "espírito"; no caso dos buscadores carismáticos, revigorados pelo Espírito Santo, mediante $\mathrm{o}$ acesso a realidades profundas que olhos comuns não conseguem ver. A circulação de pessoas, bens simbólicos, corpos, "eus" e selves são conaturais ao sagrado, ao religioso e ao espiritual, provocando duas situações. Na primeira delas, emerge a centralidade das tecnologias do eu/self, manipulações do sagrado, tornando a identidade um constante ponto de partida, sempre iniciado, nunca estável. Na segunda situação, ocorre o inverso, emerge a busca do peso, da fixação, do regramento, do anseio pela estabilidade, sobretudo ao evocar/invocar a grande tradição e o dogma; enfim, trata-se de uma busca ativa de um passado ideal, delimitado pela institucionalidade católica. Por isso mesmo, é uma tradição submetida aos poderosos fluxos de desterritorialização, dessubstancialização e descanonização, lutando para ser autoevidente e natural, coextensiva, portanto, à sociedade. 
A busca de uma memória ontológica fechada ou de uma totalidade sempre aberta sugere a emergência de um jogo entre metáfora e metafísica. Há um duplo trabalho em ação no turismo católico-carismático e na Nova Era: o do apagamento das descontinuidades entre o passado e o presente, e o da busca por um novo sujeito, no encalço de seu self profundo (além das estruturas e culturas) ou no encalço de Deus dentro de si, lugar onde, ou se encontrará com um Deus pessoal/único/absoluto ou com o cosmos, o sagrado, o mistério de si mesmo, sem bordas e sem fim.

Minha hipótese, a partir desses flashes etnográficos é de que os destroços ontológicos são encontrados no "turismo católico-carismático" e no "turismo espiritualista new age”, em duas perspectivas diferentes: uma procurando restaurar o passado; a outra, ultrapassando-o. Em ambas, identifico um viés romântico. A Nova Era com a ideia de self profundo e autêntico, continuamente buscado em cada evento, único em sua unidade, mas provisório. O turismo católico-carismático com a ideia de um self em busca de uma verdade religiosa, que encerraria o sujeito e suas experiências dentro de uma circunscrição segura, a saber: da narrativa católico-carismática. Assim, a aversão ao peso na cultura religiosa contemporânea redunda, como reação, no fascínio de certos grupos e comunidades pela suposta profundidade e densidade perdidas. Surge, então, o resgate de tradições, ritos e fronteiras fechadas, evidenciando, simbolicamente, um amplo processo de desnaturação do religioso e do sagrado (Silveira, 2007).

Por outro lado, em torno e dentro dos santuários, a plasticidade das expressões - que oscila entre a busca de fixidez e fronteiras (centro, templo mundi) e a dispersão nômade à moda Nova Era - pode ser vista como a expressão de duas forças que operam, por contrastes, a escavação das fundações metafísicas da religião, do mercado, do lazer, e da identidade social-religiosa. 


\section{REFERÊNCIAS}

ADAMI, Vítor Hugo Da Silva. O pensamento coletivo Hare Krishna e seus modos de institucionalização: um estudo sobre comunidades globalizadas e identidades locais. Tarragona: Tese de Doutorado em Antropologia Social, Universidade Rovira i Virgili, 2013.

AMARAL, Leila. Carnaval da Alma: comunidade, essência e sincretismo na Nova Era. Petrópolis: Vozes, 2000.

AMARAL, Leila. Um espírito sem lar: sobre uma dimensão 'Nova Era' da religiosidade contemporânea. In: VELHO, Otávio et al. Circuitos infinitos: comparações e religiões no Brasil, Argentina, Portugal, França e Grã-Bretanha. São Paulo: Attar Editorial, 2003. Cap. 4, p. 17-60.

AMARAL Leila. O momento de emergência de uma antropologia interpretativa: sobre a possibilidade do ‘diálogo' no encontro etnográfico. Juiz de Fora: Irmãos Justiniano, 2004 .

BARREMAN, Gerard. Por trás de muitas máscaras. In: ZALUAR Alaba (Org.).

Desvendando máscaras sociais. Rio de Janeiro: Francisco Alves, 1975. p. 30-45.

CAROZZI, Maria Julia (Org.). A Nova Era no Mercosul. Petrópolis: Vozes, 1999.

CAROZZI, Maria Julia. Nueva Era y Terapias Alternativas: Construyendo significados en el Discurso y la interacción. Buenos Aires: Ediciones de la Universidad Católica Argentina, 2000.

CAMURÇA, Marcelo Ayres. Sombras na Catedral: A Influência New Age na Igreja Católica e o Holismo da Teologia de Leonardo Boff e Frei Betto. Numen: Revista de Estudos e Pesquisa da Religião, Juiz de Fora, v. 1, n. 1, p. 85-125, ago. 1998.

CAMURÇA, Marcelo Ayres. Cuidado de si, imperativo de realização de si e produção de subjetividades em redes carismáticas da Igreja Católica no Brasil no meio universitário. História: Debates e Tendências, v. 9, n. 2, p. 348-363, jul./dez. 2009.

CARNEIRO, Sandra Maria de Sá. Novas peregrinações brasileiras e suas interfaces com o turismo. Ciencias Sociales y Religión/Ciências Sociais e Religião, Porto Alegre, ano 6, n. 6, p. 71-100, out. 2004.

CARRANZA, Brenda Maribel. Renovação Carismática Católica: origens, mudanças e tendências. Aparecida: Editora Santuário, 2000.

CESARINO, Letícia. Antropologia multissituada e a questão da escala: reflexões com base no estudo da cooperação sul-sul brasileira. Horizontes antropológicos, Porto Alegre, v. 20, n. 41, p. 19-50, jun. 2014.

COSTA, Thaísa Corrêa Palmieri. Pousada Ashram Vrajabhumi: um olhar pósmoderno sobre novos produtos turísticos. Minas Gerais, 2004, 90 f. (Trabalho de Conclusão de Curso - Graduação em Turismo), FESJ, Minas Gerais. 
CLIFFORD, James; MARCUS, Georges. Writing culture: the poetics and politics of ethnography. Berkeley: University of California Press, 1986.

CSORDAS, Thomas. The Sacred Self: a cultural phenomenology of charismatic healing. Berkeley/Los Angeles: University of California Press, 1997.

D'ANDREA, Anthony. O self perfeito e a Nova Era: individualismo e reflexividade em religiosidades pós-tradicionais. São Paulo: Loyola, 2000.

DIAS, Reinaldo; J, SILVEIRA, Emerson, Sena da. Turismo religioso: ensaios e reflexões. Campinas: Papirus, 2003.

EADE, John; SALLNOW, Michael (Org.). Contesting the sacred. The Anthropology of Christian pilgrimage. London/New York: Routledge, 1991.

ELIADE, Mircea. O espaço sagrado e a sacralização do mundo. In: ELIADE, Mircea. $\mathbf{O}$ sagrado e o profano. São Paulo: Martins Fontes, 1992. Cap. 4, p. 17-38.

ELIADE, Mircea. Tratado de História das Religiões. São Paulo: Martins Fontes, 2002.

FERNANDES, Rubem César. Aparecida: nossa rainha, senhora e mãe, saravá! In: FERNANDES, Rubem César; SACHS, Viola et al. Brasil e EUA: religião e identidade nacional. 2. ed. São Paulo: Graal, 1988. p. 45-57.

GIDDENS, Anthony. A vida em uma sociedade pós-tradicional. In: GIDDENS, Anthony. Em defesa da sociologia. Ensaios, interpretações e tréplicas. São Paulo: Editora da UNESP, 2001. p. 21-96.

GEERTZ, Clifford. Uma descrição densa: por uma teoria interpretativa da cultura. In: GEERTZ, Clifford. A interpretação das culturas. Rio de Janeiro: LTC, 2008. p. 3-25.

GEERTZ, Clifford. Um jogo absorvente: notas sobre a briga de galos balinesa. In: GEERTZ, Clifford. A interpretação das culturas. Rio de Janeiro: LTC, 2008. p. 185-214.

GUERRIERO, Silas. Movimento Hare Krishna no Brasil: uma interpretação da cultura védica na sociedade ocidental. Rever: Revista de Estudos da Religião, São Paulo, n. 1, 2001, p. 44-56, 2016. Disponível em: <http://www.pucsp.br/rever/rv1_2001/p _guerri.pdf $>$. Acesso em: 22 jun. 2016.

HANEGRAAFF, Walter. New Age Religion and western culture: esotericism in the Mirror of Secular Thought Brill. New York: Leiden, Koln, 1996.

HEELAS, Paul. The New Age Movement. Oxford: Blackwell Publishers, 1996.

HERVIEU-LÉGER, Danièle. O peregrino e o convertido: a religião em movimento, Petrópolis: Vozes, 2008. 
JUNGBLUT, Aírton L.; ADAMI, Vítor Hugo da Silva. Hinduísmos ocidentalizados e suas percepções acerca do sexo: Movimento Hare Krishna e Movimento Rajneesh. Religião e Sociedade, Rio de Janeiro, v. 37, n. 1, p. 104-121, 2017.

MAGNANI, José Guilherme C. Mystica Urbi: um estudo antropológico sobre o circuito neo-esotérico na metrópole. São Paulo: Studio Nobel, 1999a.

MAGNANI, José Guilherme C. O xamanismo urbano e a religiosidade contemporânea. Religião \& Sociedade, Rio de Janeiro, v. 20, n. 2, p. 113-140, 1999 b.

MARCUS, George. Identidades passadas, presentes e emergentes: requisitos para etnografias sobre a modernidade no final do século XX ao nível mundial. Revista de Antropologia, São Paulo, USP, n. 34, p. 197-221, 1991.

MARIZ, Cecília Loreto; MACHADO, Maria das Dores Campos. Sincretismo e trânsito religioso: comparando carismáticos e pentecostais. Comunicações do ISER, Rio de Janeiro, n. 45, p. 24-34, 1994.

MARIZ, Cecília Loreto. A Renovação Carismática Católica: uma igreja dentro da Igreja? Civitas: Revista de Ciências Sociais, Porto Alegre, v. 3, n. 1, p. 169-186, jun. 2003.

MAUÉS, Heraldo. Bailando com o Senhor: técnicas corporais de culto e louvor (o êxtase e o transe como técnicas corporais). Revista de Antropologia, São Paulo, v. 46, n. 1, p. 940, 2003.

MINAYO, Maria C. Souza. Los conceptos estructurantes de la investigación cualitativa. Salud Colectiva, v. 6, n. 3, p. 251-261, 2010.

MONTERO, Paula. Questões para a etnografia numa sociedade mundial. Novos Estudos Cebrap, São Paulo, n. 36, p. 161-77, 1993.

OLIVEIRA, Eliane Martins de. O mergulho no Espírito de Deus: diálogos (im)possíveis entre a Nova Era e a Renovação Carismática Católica na Comunidade de Vida no Espírito Canção Nova. 2003. 79 f. Dissertação (Mestrado em Ciências Sociais) Universidade do Estado do Rio de Janeiro, Rio de Janeiro, 2003.

OLIVEIRA, Eliane Martins de. Semântica da Canção Nova: relações de duplo vínculo e segredo em pesquisas sobre a Comunidade de Vida Canção Nova. In: SILVEIRA, Emerson Sena da; SOFIATI, Flávio Munhoz (Org.). Novas leituras do Campo Religioso brasileiro. São Paulo: Ideias \& Letras, 2014. p. 126-155.

OLIVEIRA, Christian Dennys M. de. Turismo religioso. São Paulo: Aleph, 2004.

OLIVEIRA, Christian Dennys M. de. Turismo religioso no Brasil: construindo um investimento sócio-cultural. In: TRIGO, L. G. (Coord.). Turismo: análises regionais e globais. São Paulo: Rocca, 2005. p. 325-344.

OLIVEIRA, Christian Dennys M. de. Desafios contemporâneos das Cidades-Santuários no estado do Ceará (Brasil): políticas patrimoniais e diocesanas. Revista Geosaberes, v. 1, n. 1, 2010, p. 37-51. 
OLIVEIRA, Luciane. O poder do discurso carismático, Estudos de Sociologia, Revista do Programa de Pós-Graduação em Sociologia da UFPE, v. 13, n. 1, p. 77-92, 2007.

OLIVEIRA, Jefferson Rodrigues de. Canção Nova e as peregrinações modernas: hierápolis carismática de Cachoeira Paulista-SP, Jundiaí: Paco Editorial, 2015.

PRANDI, Reginaldo. Um sopro do espírito: a renovação conservadora do catolicismo. São Paulo: Edusp/Fapesp, 1997.

ROSENDAHL, Zeny. Espaço e religião: uma abordagem geográfica. Rio de Janeiro: EdUERJ, 1996.

ROSENDAHL, Zeny. Hierópolis: o sagrado e o urbano. Rio de Janeiro: EdUERJ, 1999.

ROSENDAHL, Zeny. Espaço, cultura e religião: dimensões de análise. In: CORRÊA, Roberto Lobato e ROSENDAHL, Zeny. (Orgs.). Introdução a Geografia Cultural. Rio de Janeiro: Bertrand Brasil, 2003. p. 187-224.

SANCHIS, Pierre. Modernidade e Pós-modernidade. Análise \& Conjuntura, Belo Horizonte, v. 7, n. 2-3, p. 10-20, maio-dez. 1992.

SECALL, Rafael Esteve. Turismo y religión: aproximación a la historia del turismo religioso. Universidad de Málaga: Servicio de publicaciones e intercambio científico, 2002.

SILVEIRA, Emerson José Sena da; MORAES JÚNIOR, Manoel Ribeiro de. A dimensão teórica dos estudos da religião. Horizontes histórico, epistemológico e metodológico nas Ciências da Religião. São Paulo: Fonte Editorial, 2017.

STEIL, Carlos Alberto. O Sertão das romarias: um estudo antropológico sobre o Santuário de Bom Jesus da Lapa - Bahia. Petrópolis: Vozes, 1996.

STEIL, Carlos Alberto. A igreja dos pobres: da secularização à mística. Religião \& Sociedade, Rio de Janeiro, v. 19, n. 2, p. 61-76, 1998.

STEIL, Carlos Alberto. Aparições marianas contemporâneas e carismatismo católico. In: SANCHIS, Pierre (Org.). Fiéis e cidadãos: percursos de sincretismo no Brasil. Rio de Janeiro: EDUERJ, 2001. p. 117-146.

STEIL, Carlos Alberto. Renovação Carismática Católica: porta de entrada ou de saída do catolicismo? Uma etnografia do Grupo São José, Porto Alegre (RS). Religião \& Sociedade, Rio de Janeiro, v. 24, n. 1, p. 11-36, 2004.

TONIOL, Rodrigo; STEIL, Carlos Alberto. Ecologia, Nova Era e Peregrinação: uma etnografia da experiência de caminhadas na Associação dos Amigos do Caminho de Santiago de Compostela do Rio Grande do Sul. Debates do NER, Porto Alegre, ano 11, v. 1, n. 17, p. 97-120, jan.-jun. 2010.

TURNER, Victor. Pilgrimage and communitas. Studio Missionalia, n. 23, p. 305-327, jun. 1974 . 
TURNER, Victor. Peregrinações como processos sociais. In: TURNER, Victor. Dramas, campos e metáforas: ação simbólica na sociedade humana. Niterói: EdUFF, 2008. p. 155-214.

TURNER, Victor; TURNER, Edith. Image and pilgrimage in Christian culture. Oxford: Basil Blackwell, 1978.

URPI, Montoya Uriarte. O que é fazer etnografia para os antropólogos, Ponto Urbe [Online], 11 | 2012, postado online no dia 14 março 2014, consultado no dia 18 abril 2018. Disponível em: <http://journals.openedition.org/pontourbe/300>. DOI:

$10.4000 /$ pontour be.300

VAZ, Pe. Carlos Henrique de Lima. Escritos de Filosofia VII: raízes da modernidade. São Paulo: Edições Loyola, 2002.

SILVEIRA, Emerson J. Sena da. Turismo religioso, pós-modernidade e mercado. In: DIAS, Reinaldo. Turismo religioso: ensaios e reflexões. Campinas: Alínea, 2003a. p. 15-30.

SILVEIRA, Emerson J. Sena da. O 'pop' no espírito: festa, consumo e artifício no movimento carismático. In: PEREIRA, Mabel Salgado; CAMURÇA, Marcelo Ayres. Festa e religião: imaginário e sociedade em Minas Gerais. Juiz de Fora: Templo Editora. 2003b. p. 30-48.

SILVEIRA, Emerson J. Sena da. Turismo religioso popular? Entre a ambiguidade conceitual e as oportunidades de mercado. Revista de Antropología Experimental, Granda/Espanha, v. 4, n. 4, p. 4, 2004.

SILVEIRA, Emerson J. Sena da. O ‘turismo religioso’ e a desterritorialização da religião. In: FOLLMANN, José Ivo; LOPES, José Rogério (Org.). Diversidade religiosa, imagens e identidade. Porto Alegre: Armazém Digital, 2007. p. 255-273.

SILVEIRA, Emerson J. Sena da. Tradicionalidade e estratégia identitária no catolicismo: do turismo religioso os retiros religioso-ecológicos. In: SILVEIRA, Emerson Sena da; SOFIATI, Flávio Munhoz (Org.). Novas leituras do Campo Religioso brasileiro. São Paulo: Ideias \& Letras, 2014. p. 16-30.

SILVEIRA, Emerson J. Sena da. New Age Consumption. In: Henri P. P. Gooren (Org.). Encyclopedia of Latin American Religions. 1. ed. Springer International Publish: Springer International Publishing, 2015a. p. 1-6.

SILVEIRA, Emerson J. Sena da. New Age Trade Show. In: Henri P. P. Gooren (Org.). Encyclopedia of Latin American Religions. 1. ed. Springer International Publish: Springer International Publishing, 2015b. p. 1-5.

WERNET, Augustin. Peregrinação a Aparecida: das romarias programadas ao turismo religioso. In: RODRIGUES, Adyr B. (Org.). Turismo, modernidade, globalização. São Paulo: Hucitec, 1992. p. 20-45. 